\title{
Bim nuclear translocation and inactivation by HHV-8 interferon regulatory factor 1
}

\author{
Young Choi, John Nicholas \\ From $12^{\text {th }}$ International Conference on Malignancies in AIDS and Other Acquired Immunodeficiencies \\ (ICMAOI) \\ Bethesda, MD, USA. 26-27 April, 2010
}

Viral replication efficiency is in large part governed by the ability of viruses to counteract pro-apoptotic signals induced by infection of host cells. In HHV-8, one group of proteins acting to suppress the host's innate defenses is the set of four viral interferon regulatory factors (vIRFs 14), which act to block cellular IRF activities in addition to targeting and inhibiting p53 and other inducers of apoptosis. We observed that in a large proportion of endothelial cells supporting lytic reactivation, the normally cytoplasmic pro-apoptotic BH3-only protein Bim, a negative regulator of HHV-8 productive replication, was localized in the nucleus. Nuclear localization of Bim could be induced in cells cotransfected with vIRF-1, and confocal microscopy identified co-localization of VIRF-1 and Bim in the nuclei of lytically reactivated cells. Physical association of vIRF-1 and Bim was identified in co-precipitation experiments using both transfected cell lysates and purified recombinant vIRF-1 and Bim. In vitro binding studies using a series of truncation and point variants of VIRF-1 enabled precise mapping of the Bim-interacting residues (Bimbinding domain, BBD) of vIRF-1. Wild-type, but not mutated, BBD fused to a nuclear localization signal was sufficient to induce Bim nuclear translocation in transfected cells; BBD-mutated vIRF-1 proteins were unable to do so or to protect cells from Bim-induced apoptosis. Depletion of endogenous vIRF-1 led to reductions in virus production and increased apoptosis in lytically reactivated endothelial cultures, while transduced expression of wildtype vIRF-1 promoted virus production and inhibited apoptosis. Experimental utilization of Bim-refractory vIRF1 variants revealed the importance of vIRF-1:Bim interaction, specifically, for pro-replication and anti-apoptotic

\footnotetext{
*Correspondence: nichojo@jhmi.edu

Department of Oncology, Johns Hopkins University School of Medicine, Baltimore, MD, USA

Full list of author information is available at the end of the article
}

activity of vIRF-1. Furthermore, blocking of the interaction with cell-permeable peptide corresponding to the Bimbinding region of vIRF-1 confirmed the relevance of vIRF1:Bim association to vIRF-1 pro-replication activity. To our knowledge, this is the first report of an IRF protein that interacts with a Bcl-2 family member and of nuclear sequestration of Bim or any other member of the family as a means of inactivation. Our data reveal a novel mechanism utilized by a virus to control replication-induced apoptosis and suggest that inhibitory targeting of vIRF-1: Bim interaction may provide an effective antiviral strategy.

\section{Acknowledgements}

This article has been published as part of Infectious Agents and Cancer Volume 5 Supplement 1, 2010: Proceedings of the $12^{\text {th }}$ International Conference on Malignancies in AIDS and Other Acquired Immunodeficiencies (ICMAOI). The full contents of the supplement are available online at http://www.biomedcentral.com/1750-9378/5?issue=S1.

Published: 11 October 2010

doi:10.1186/1750-9378-5-S1-A7

Cite this article as: Choi and Nicholas: Bim nuclear translocation and inactivation by HHV-8 interferon regulatory factor 1. Infectious Agents and Cancer 2010 5(Suppl 1):A7.

Submit your next manuscript to BioMed Central and take full advantage of:

- Convenient online submission

- Thorough peer review

- No space constraints or color figure charges

- Immediate publication on acceptance

- Inclusion in PubMed, CAS, Scopus and Google Scholar

- Research which is freely available for redistribution

Submit your manuscript at www.biomedcentral.com/submit
Ciomed Central 